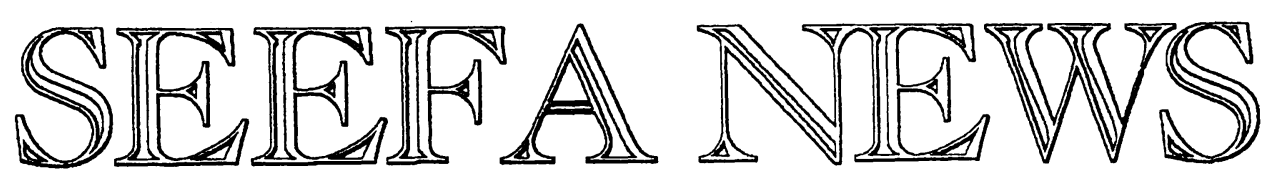

The Newsletter of the Slavic and East European Folklore Association

Volume II, Number 1, Spring 1997

\title{
A Message from the President
}

The SEEFA business meeting took place on November 16th during the AAASS convention in Boston last year. Not only were we once again meeting in a cramped room, but we also were pressed for time. Reports were given by the president James Bailey and secretary-treasurer Jeanmarie Rouhier Willoughby. Bruce McClellan, who had just resigned as newsletter editor to take a position with IREX in Russia, was unable to attend. The new editor is Jonathan Perkins who is a graduate student at the University of Kansas.

SEEFA continues to grow. We have received non-profit status for the organization and we also applied to AAASS and received approval for affiliation. This gives us one "free" panel at the convention and the right to a meeting room. Unfortunately so many proposals were made for panels at the 1997 convention that affiliated organizations have been asked to forego special meeting rooms. To date nothing more has been said about this but the prospect looms that we once again will be jammed into someone's hotel room.

Much time was devoted to the newsletter and to the web page. It was suggested that items be included such as works in progress, dissertations on folklore, syllabi for folklore courses, notices about conferences, mini-reviews, descriptions of folklore programs, opportunities for field work, and surveys of recent studies of the folklore in Eastern Europe and the former Soviet Union. Needless to say, such coverage can be achieved only when members volunteer information. Especially needed are contributions about the folklore of traditions other than Russian. While folklorists in Russian have responded well to
SEEFA and have agreed to write short pieces about their current work, one would wish that folklorists in other traditions would participate more. This of course brings up the role of foreign scholars in SEEFA. Considering the fact that so many people from other countries give papers at the annual AAASS convention, SEEFA might wish to invite such folklorists to take part in future panels. Such arrangements might prove beneficial to everyone in volved.

A question was brought up about the availability of audio-visual materials for folklore. The three films about Russian calendar rituals made by Galina Shapovalova were mentioned - a note about how to purchase them is on the final page of this newsletter. Since the University of Virginia, Charlottesville has extensive holdings, Jan Perkowski promised to compile a list of materials that should appear in the next newsletter. Any information about such items, however brief, would be appreciated. Ronelle Alexander spoke about the Fifth Lord Conference that was held in Almaty and about possible future plans for such conferences. Linda Ivanits spoke about the I. E. Sharpe series on East European folklore.

After the panel on epics, which Mrs. Albert Lord attended, we went across the river to Harvard Widener Library where we met in the room of the Milman Parry collection. Once again there was standing room only for us to hear Mrs. Lord talk about her husband and about some of his experiences collecting in Yugoslavia. It was a memorable time for which we have to thank Thomas Butler and Margaret Beissinger.

-James Bailey, University of Wisconsin 


\section{SEEFA OFFICERS 1997-1998}

\section{President}

JAMES O. BAILEY

Slavic Department

1432 Van Hise Hall

1220 Linden Dr.

University of Wisconsin

Madison, WI 53706

(608) 271-3824

jobailey@facstaff.wisc.edu

Vice President

JAN L. PERKOWSKI

Slavic Department

109 Cabell Hall

University of Virginia

Charlottesville, Virginia 22903

(804) 924-6686

perkowski@virginia.edu

Secretary-Treasurer

JEANMARIE ROUHIER-

WILLOUGHBY

Department of Russian and Eastern Studies

1055 Patterson Office Tower

University of Kentucky

Lexington, KY 40506-0027

fax: (606) 257-3743

jrouhie@pop.uky.edu

Member-at-Large

RONELLE ALEXANDER

Slavic Department

5414 Dwinelle Hall

University of California

Berkeley, CA 94720

(510) 642-8301

Alexande@qal.berkeley.edu

\section{Newsletter Editor}

JONATHAN PERKINS

Dept. of Slavic Languages and Literatures

2134 Wescoe Hall

University of Kansas

Lawrence, KS 66045

(913) 864-3313

jperkins@falcon.cc.ukans.edu

\section{A Note from the Treasurer}

The most important news from a financial point of view is that the IRS approved us for non-profit status this fall. The arrangement will need to be reviewed in several years to ensure that we are not making a huge profit on our yearly dues. Hardly likely, but nevertheless, the IRS has its rules. The current financial holdings of the organization total $\$ 624.39$. Our membership has grown to a total of forty eight over the last year. However, our student membership is still quite low. For the sake of the future of the discipline as well for the organization, we ask that you mention SEEFA to your students and encourage them to join.

This column serves as the official reminder that it is time to renew your SEEFA membership for 1997. While many of you have already renewed, we ask those of you who have not yet sent in a check, to please submit your dues with an update of the following information: Name; home address; work address (please indicate preferred mailing address); email; fax number; telephone number (home and work); areas of interest in folklore; research in progress; suggestions for the newsletter.

The check should be made out to SEEFA and sent to the secretary/treasurer at the following address: J. Rouhier-Willoughby, 1055 Patterson Office Tower, Dept. of Russian and Eastern Studies, University of Kentucky, Lexington, KY 40506. Thanks to all of you who have already submitted your dues and to our new members for their support of the organization.

- Jeanmarie Rouhier-Willoughby

\section{Correction}

In the piece "Bibliographic Series: Russian Folklore" by Tatyana Ivanova the dates covered in the index published by the new private publishing house 'Dimitri Bulanin' in 1996 were given incorrectly. The volume covers the years $1800-1855$. 


\section{Folklore Expedition of the Russian Institute for the History of the Arts}

A folklore expedition entitled "The Bearer of the Folklore Tradition" was carried out from June through September 1996. To the experts of the Russian Humanities Scholarly Fund this program seemed worthy of encouragement and, as a result, we, the participants of the expedition (members and graduate students of the Folklore Sector of the Institute), were awarded a grant.

The personality of a connoisseur and performer of folklore has long interested Russian folklorists. An impressive list of literature, beginning, perhaps, with the portraits of epic singers sketched by A. F. Hilferding in his "Onega Bylinas," reflects this trend. However, the subject has acquired renewed attention in each historical period. For example, during the economic reforms that are now taking place in the Russian village, the personality of the performer has once again become important to folklorists.

We went to the countryside fearing that traditional rituals and folklore would be buried under current events. Thus, before the expedition set out, government regulations appeared about granting each peasant an allotment of land. However, the peasants with whom we dealt (our informants were elderly people) were indifferent to this. Old people were not capable of undertaking such a holding and they had no equipment for cultivating the land since it was too expensive to buy. What most disturbed people was the many months' delay in the payment of pensions and salaries.

From time to time there were instances when old women would refuse to recall the songs and rituals of their youth - they were not in a mood to do so. But nevertheless, the time, during which traditional folklore decays and is forgotten, has its own existence and depends, far less than can be supposed, on the latest political events.

According to the program, the participants of the expedition visited various regions of northern Russia, that is, the Archangelsk, Vologda, Novgorod, Pskov, and Tver Districts. The trip was divided into two parts: in the beginning each of the participants went to "his" or "her" region separately not only to embody the general idea of the expedition within each individual's plans and to pursue them on the spot, but also to choose an area where we could go all together on a second trip and could study the region's folklore tradition exhaustively.

The participants of the expedition had various specialties: folklore philology (A. Nekrylova, M. Lur'e), ethnomusicology (V. Lapin, M. Lobanov, M. Roditeleva), musical instruments (A. Romodin), and ethnography (S. Kuchepatova). Each had his or her own long established scholarly interests and each worked individually as he or she understood the bearer of the folklore tradition. Although we had assumed this division from the very beginning, when we met and discussed the initial work that had been accomplished, we nevertheless were able to arrive at a general understanding. We then made a second trip solely to the western part of the Andreapol Region of the Tver District.

The most numerous collected materials represent calendar, ritual, and wedding songs, a multitude of chastushkas which maintain a lively existence, several traditional tales, stories about demonological personages, and a multitude of recordings of rural accordion players and of instruments that are more rarely met in the village today - balalaikas, violins, and shepherd's drums (barabanka). In addition, there are the stories of village residents of various ages (including children) who are, in the opinion of the residents, bearers of folklore, and recordings of talks with the bearers themselves. Materials concerning the typology of singers, musician instrumentalists, and tellers of tales as well as materials on the typology of population centers from the point of view of the conditions that support folklore traditions there were also gathered.

- M. A. Lobanov, Russian Institute for the History of the Arts, St. Petersburg 


\section{Recent Works on Bulgarian Folk Verbal Art}

Although the last decade has witnessed a significant interest in more modern manifestations of the dynamics of folklore, Bulgarian folklorists have not ceased searching for new approaches to the so-called "classical" folklore heritage. Radost Ivanova's book "Epos-Ritual-Myth" is one example of this. The author adopts E. M. Meletinsky's "evolutionary" approach and focuses on genesis and gradual change in the epic tradition from archaic mythology to more recent historical epic narratives. Ritual and myth in this study serve as a cultural "medium" for the existence of epos in time.

Radost Ivanova attempts to reconstruct those epic works, of whose existence there is only indirect evidence, and which are closely interwoven with seasonal rituals and myths. The central epic character of Marko Kraleviti is analyzed as composed of multiple layers of features, revealing a more archaic image hidden behind that of the Prilep ruler. The more archaic figure is regarded as the "culture hero" who engages in contests with demons controlling water sources. Viewed from this perspective, the older epic narrative is linked to a group of myths and rites associated with the cosmogonic act of the vernal renewal of vegetation. Analysis of a cycle of seasonal rites throughout the Balkans and the Mediterranean region leads Ivanova to view these rites and the older epos as typological parallels of the same "calendrical" version of the creation myth. The subsequent "historicization" of the archaic epic model has led to its direct link with historical persons and events, while the connection to the myth has gradually faded. (Marko at this stage fights a real ethnic enemy and frees his enslaved fellow countrymen, yet the images of the hero's helpers, the antagonist, and even the chains of slaves still yield evidence of the mythological layers of the epic tradition.)

The epos-ritual connection is also explored in "evolutionary" terms on the basis of the wedding theme as found in songs about the marriage of the epic hero. A parallel is sought between the "culture hero" and the epic "bridegroom" in terms of their actions and semantics. Plamen Bochkov's book "The Unknown Hero" is an attempt to analyze lesser known or forgotten epic themes from an unusual perspective. The work leads the reader through the complex set of characters found in the Bulgarian epos and reveals through them the changing fate of the Bulgarian people over time. Analysis is carried out within the context of Balkan history in the Middle Ages, an epoch of heroes, blind singers and their long songs. "EposEthnos-Ethos" situates the Bulgarian epic tradition in the context of Slavic and Balkan cultures. It also offers some new approaches, and raises new issues.

Bulgarian folk narratives have also been the subject of numerous recent publications. Perhaps the most significant among them is the "Index of Bulgarian Folktales" by Liliana Daskalova Perkowski, Doroteia Dobreva, Iordanka Kotseva, and Evgeniia Mitseva. The authors, research scholars from the Institute of Folklore of the Bulgarian Academy of Sciences, completed this complex volume in 1985, but it appeared only a decade later due to circumstances related to problems and recent changes in publishing.

The (tale-type) Index presents in a systematic form more than 5,500 existing versions of tales collected between 1830 and 1985 and scattered in various published and archival sources. It is preceded by an earlier attempt at classification made by Mikhail Arnaudov (1905), which, however, is rather limited in terms of genre scope and number of texts. Earlier collections of tales often contained references to previously published versions of the texts. However, it was impossible to obtain comprehensive data about all folklore subjectmatter and themes, and all tale versions and variants. Furthermore, given the international distribution of tales and motifs and their tendency to migrate, comparative research is only possible through quick and easy access to a reliable and comprehensive reference source, especially one which follows a well-known, internationally established model. Therefore, the Bulgarian taletype index has adopted the classification system of Antti Aarne and Stith Thompson's "The Types of the Folktale," whose practical usefulness has been undisputed, despite the continuing discussion about its merits and flaws. The authors had to introduce some changes, while strictly adhering to the international model: tale-type titles are sometimes modified to reflect an established national tradition; some subgenres are also named in accordance with established local practice at the time (e.g., legendary, instead of religious tales). New, specifically Bulgarian, material is 
incorporated through careful use of Thompson's patterns of marking types and subtypes, and by indicating all newly introduced "oicotypes" with an asterisk preceding the type number. Close to 900 new entries are thus introduced into what are considered to be the most appropriate available slots. Each unit (type, subtype) is furnished with a title, plot scheme, ample notes with crossreferences to other types and indexes, notes on existing studies, on parallels in folk songs, parables and proverbs, etc. More importantly, precise cross-references are provided to the indexes of Turkish folktales (of EberhardBoratav) and East Slavic tales (of L. Barag et al.) thus connecting three major narrative traditions which have undergone mutual influence over time.

More than 5,500 texts have been selected, analyzed, and systematized after a careful and thorough search through scholarly and popular collections and publications, regional studies, periodicals, and major archives where folklore records have been stored for a long time. For various reasons, not all regions of Bulgaria have been equally well covered by collectors in the past. There remains, therefore, a certain gap due to the disproportionate coverage of the country's territory. The Index, however, being an open system by design, has laid the foundation upon which further additions can be made if necessary.

Fitting a narrative tradition as as diverse and dynamic as the Bulgarian one into a rigorous classification scheme previously established to accommodate other cultural traditions, is by no means an easy task. The authors have managed to follow strictly the AT scheme, without displacing, misplacing or combining tale-types and, instead, have expanded the cross- references among the latter. There has been a danger of doing away with the characteristics of the national narrative material while fitting it into the AT model, particularly in regard to such aspects as tale classification and the understanding of the taletype as an autonomous narrative, that is, one told as a single story. However, the authors have presented each type in a way that allows the international scholar, familiar with the AT Index, to find his/her way around in the material and, at the same time, to grasp the specific nature of the national tradition. Each type is introduced by means of an extensive yet sparse plot scheme, with the more elaborate types, e.g., those of magic or romantic tales, broken down into chief constituent parts and marked by a special system of markers. The bibliographic data for each version is followed by a short formula. This manner of presentation allows for the reading (reconstruction) of each version. Often, specific details are also given that further characterize each single version.

The volume also comes with an elaborate index of names and objects, as well as a bibliography of all major studies on Bulgarian folktales. "Bulgarian Folk Ballads" by Liliana Bogdanova et al. presents this genre in a comprehensive fashion. Mainly new recordings from a variety of regions in Bulgaria are included. Part I includes mythical, religious, and legendary songs and ballads. Part II presents ballads of everyday life, historical events and persons, as well as ballads about the life of rebels and outlaws. Each text is supplied with ample notes and a bibliography of all published versions. The second volume also contains all relevant indexes, data about singers/informants and collectors, and a glossary. "Nauka i izkustvo" introduces a new series of folklore material with the books compiled by Albena Georgieva, Evgeniia Mitseva, Doroteia Dobreva and Svetla Petkova. It follows two earlier series -- "Bulgarsko narodno tvorchestvo" (12 vols, 1961-63) and "Bulgarska narodna poeziia i proza" (7 vols, 1981-83), in which all major verbal genres are represented by selected annotated texts and by extensive introductions. The same pattern is followed in the new series. The main difference is that in the new series, each book focuses on a major theme and the texts published are supplemented and/or "interpreted," as if "from within," by other related folk material, an approach that creates the semantic context inseparable from the text. Thus, A. Georgieva's book focuses on folk legends of origin and ethical issues, E. Mitseva's on folk demonology, D. Dobreva's deals with jokes and anecdotes, and S. Petkova's book deals with folklore about the plague and other pestilence. Among the texts are earlier recordings as well as more recent and previously unpublished ones. Each text is accompanied by other related records of folk concepts and beliefs, songs and stories, ritual practices, proverbs and riddles, as well as by detailed notes and references. Comprehensive introductory essays provide an in-depth analysis of the corresponding matter.

\section{- Liliana Perkowski, University of Wisconsin}




\section{The Development of Conceptual Dictionaries of Oral Folk Culture}

In the Institute of Linguistics of the Russian Academy of Sciences work is being carried out on a lexical description of the language of Russian folklore according to genre distinctions. The texts of religious verses (dukhovnye stikhi) and lamentations have been selected for comparison. Besides the director S. E. Nikitina, E. I. Kukushkina is also taking part in the work.

A model of the lexical entry in a thesaurus, a variant of which appears in S. E. Nikitina's book "Oral Folk Culture and Linguistic Consciousness" (Moscow, 1993), serves as the main instrument for investigating the folklore word. At present each entry consists of four parts. The first includes information about the frequency of a word in the selected texts, its grammatical characteristics, word formation, phonetic and morphological variants, and a brief interpretation. The second part of a lexical entry, the thesaurus proper, represents an analogue of the questionnaire which the head word "answers" with words or word combinations in the same language - this generates the semantic explication of the word. The thesaurus comprises about forty points, that is, names of the semantic relations that are typical for folklore texts - static and dynamic (circumstantial), equivalent, and hierarchal.

It is essential that the same thesaurus pattern be used for words of different types, such as the names of objects, actions, or people, because this, depending on how the thesaurus pattern is filled, will permit a formalized and non-trivial classification of folklore words to be received. An illustrative part follows the thesaurus part. The last part of the lexical entry represents a commentary which includes technical as well as remarks about content and which sometimes may be extensive.

At the present time, with a varying degree of completeness in the commentary, more than one hundred words in the texts of religious verses and lamentations have been described. Among them have been delineated groups of words that designate the sphere of speech (iazyk, rech', imia, golos/glas, slovo, govorit', nazyvat'), basic elements of the human personality (um, razum, dusha, serdtse, telo/plot'), kindred relations (batiushka/otets, matush ka/mat'), and spatial elements (doroga, put', more, zemlia), descriptions of which clearly show differences among genres in a general folklore model of the world. A modified model of the lexical entry has been used for describing the terminology of the spiritual culture of Russian confessional groups (Old Believers, Dukhobors, and Molokans).

- S. E. Nikitina. Institut iazykoznaniia, Moscow

\section{SEEFA at 1997 AAASS Convention}

It appears that SEEFA is attracting people to the folklore sessions at AAASS. While we had three sessions on folklore and two related sessions at the last convention, some seven sessions have been approved for the next convention. The following people have had panels accepted: James Bailey, "Aspects of the Slavic Oral Epic Tradition"; Anne Ingram, "Ukrainian Folklore"; Emil Draitser, "Russian Humorous Folklore"; George Kalbouss, "The Slavic and East European Heritage in the United States"; Jann Lacoss, "Reflections on Childlore: Children's Folklore as a Cultural Mirror"; Robert Rothstein, "Twentieth-Century Readings of Traditional Russian Folklore"; Guntis Smidchens, "Finno - Ugric Identity Today."

For information about the "Peasant Consortium" contact Christine Worobec, Department of History, P.O.Box 5190, Kent State University, Kent, OH 442420001. Email: cworobec@kentvs.kent.edu.

For information about the "Popular Culture Association" write to Professor Ray B. Browne, Department of Popular Culture, Bowling Green State University, Bowling Green, $\mathrm{OH}$ 43403. Telephone: (419) $372-7865$ 


\section{The Russian Journal "Zhivaia starina"}

From 1890 to 1918 the Russian Geographic Society (St. Petersburg) published the journal "Zhivaia starina." To the present day its publications offer a source of information about folklore genres, beliefs, mythology, and other aspects of folk culture. In 1994 the State Republican Center of Russian Folklore (Moscow) revived "Zhivaia starina," the main editor being the recently deceased N. I. Tolstoy. The editorial board has taken into consideration the best traditions of its prerevolutionary predecessor. Together with articles on classical genres of folk literature, surveys and reviews, a chronicle of events, and bibliographies of new publications occupy an important place. As though in contradiction to the name of the journal, works about contemporary Russian folklore are given much space. Unlike the old "Zhivaia starina," the new publication, which comes out four times a year, is richly illustrated.

"Zhivaia starina" serves as a link between the scholarship of the past and that of the present day. The journal pays particular attention to those scholars who have made the finest contributions to the study of Russian folklore. In the journal's first issue in 1994, articles are devoted to the centenary of the birth of P. G. Bogatyrev; in the second issue A. I. Nikiforov, who is known for his works about the Russian folk tale, is remembered; the third issue for 1995 is dedicated to V1. Ia. Propp; and in the fourth issue for 1995 materials are presented about P. I. Riabinin-Andreev, one representative from the family of epic singers in Zaonezhia. The journal also strives to establish links between Russian and world scholarship. For example, B. N. Putilov writes about Albert Lord (1994, no. 2) and T. G. Ivanova offers a review about the Russian edition of Lord's book "The Singer of Tales" (1996, no. 3). Russian scholars have also been acquainted with the works of Bronislav Malinovski (1994, no. 4).

Almost all issues of "Zhivaia starina" touch upon folk beliefs, mythology, and rituals, thus reflecting the tone set by N. I. Tolstoy in his articles based on Common Slavic materials
(1994, no. 2 ; 1996 , no. 1,2 ). Mythological personages are at the center of attention in one issue (1996, no. 1); a large section is devoted to mummery (1995, no. 2); and the ritual log ceremonies of various peoples are examined (1995, no. 4).

Perestroika in Russia touched every aspect of the life in the country, including the study of folklore where many previously forbidden subjects were opened to scholarship. For instance, not only pagan ideas, but also Christian motifs are now being included among "folk beliefs"; "orthodoxy and folk culture" are the subject of one issue (1994, no. 3); and religious verses (dukhovnye stikhi), whose study was prominent in prerevolutionary scholarship, have now been recognized as belonging to folklore (1994, no. 1,$3 ; 1995,1$; 1996, 1).

The journal, responding to trends in the study of folklore in Russia today, reflects the interest of scholars in the present day culture of the Russian people: contemporary mythological stories among campers (1996, no. 1); anecdotes (1995, no. 1); contemporary legends about Petersburg (1995, no. 1); songs among the prisoners of Stalin's camps (1995, no. 1); songs of juvenile criminals (1995, no. 1); and children's folklore (1995, no. 2). The spiritual culture of the people is examined not only in its oral, but also in its written form - the fourth issue for 1994 presents articles about folk beliefs in Old Russian literature. However, "Zhivaia starina" also covers material culture, something that is evident in the third issue for 1996 where articles appear about the worshiping of crosses at different times and in different regions of Russia, as well as works about the semiotic origin of the shroud in the culture of various peoples.

One hopes that the revived journal "Zhivaia starina" will have a long and productive existence.

- Tatyana Ivanova, Pushkin House, Petersburg 


\section{Announcements}

The Folklore Sector of the Russian Institute for the History of the Arts would welcome enquiries about the participation of American students and folklorists in future expeditions should funding become available. Contact M. A. Lobanov, Rusșia, 190000, St. Petersburg, Isaakievskaia pl., 5, Rossiiskii institut istorii iskusstv, Sektor folklora. Fax: 011/7/812/315 -7202.

The late St. Petersburg folklorist Galina Gregorevna Shapovalova made three films entitled "Winter and Spring Holidays," "Summer and Fall Holidays," and "The Wedding Ceremony." The films were "staged" by the peasants in one Russian village in the northern Volga area where she had collected folklore materials. Ronelle Alexander, James Bailey, and Pat Arant have video copies of the films and Pat has translated the running commentary. Those interested in purchasing a VHS video of these films should contact Viktor Ivanovich Mikhailov, Direktor, Audio - visual'nyi tsentr SanktPeterburgskogo universiteta, Russia, 199034, St.
Petersburg, Universitetskaia naberezhnaia 7/9. Telephone: (011-78-12) 218-9520. Fax: (01178-12) 218-31-84. The cost is $\$ 100$ per video. Arrangements for payment should be made in advance.

At the SEEFA meeting last November Natalie Kononenko introduced Yelena and Sergei Minyonok who are folklorists at the Institute of World Literature, RAN, Moscow. They have been carrying on collection work in the Smolensk, Kaluga, and Bryansk Provinces under a grant received from Earthwatch. Volunteers may take part in four expeditions that have been scheduled for the 1997- 1998 season: team 1: June 29 - July 12 , 1997; team 2: July $16-30,1997$; team 3 : August 2-16, 1997; team 4: January 15-27, 1998. For information contact Earthwatch, 680 Mount Auburn St., P. O. Box 9104, Watertown, MA 02272-9924. Telephone: (617) 926-8200. FAX: (617) 926-8532. Send e-mail to info@earthwatch.org. You can see their website at http://www.earthwatch.org/x/Xminyonok.html.

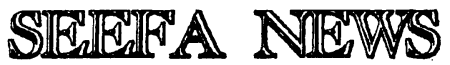

Jonathan Perkins, Editor

Dept. of Slavic Languages and Literatures

2134 Wescoe Hall

University of Kansas

Lawrence, KS 66045 